\title{
Prestasi Belajar Siswa Dalam Pembelajaran Kooperatif Tipe TAI dan Jigsaw Ditinjau Dari Kecerdasan Majemuk
}

\author{
Arif Ganda Nugroho ${ }^{1}$ dan Muhammad Husni \\ ${ }^{12}$ Universitas Muhammadiyah Banjarmasin \\ arif.gnugroho@gmail.com
}

\begin{abstract}
The purpose of this study was to determine student achievement in the TAI and Jigsaw cooperative learning model in terms of multiple intelligences. This research method is a quasi experiment. The population of this study was students of Class VIII Middle Schools in the city of Banjarmasin, while the sample was VIII Class students of SMPN 1 Banjarmasin, SMPN 7 Banjarmasin and SMPN 14 Banjarmasin. Data analysis was performed inferential statistics. The results of the study indicate that (1) There are significant differences in student achievement in each of the TAI and Jigsaw cooperative learning models before and after treatment; (2) there is no significant difference in student achievement between linguistic intelligence, mathematical logic and others; (3) there is no significant difference in student achievement between linguistic intelligence, mathematical logic and others in the implementation of the TAI type learning model; (4) there is no significant difference in student achievement between linguistic intelligence, mathematical logic and others in the implementation of Jigsaw type learning models; (5) There is a significant difference between students' learning achievement and linguistic intelligence between learning models type TAI and Jigsaw
\end{abstract}

Keywords: TAI, Jigsaw, Multipple Intelligences, Mathematics

\begin{abstract}
Abstrak :. Tujuan dalam penelitian ini adalah untuk mengetahui prestasi belajar siswa pada model pembelajaran kooperatif tipe TAI dan Jigsaw ditinjau dari kecerdasan majemuk. Metode penelitian ini adalah kuasi eksperimen. Populasi penelitian ini adalah siswa SMP Kelas VIII se-kota Banjarmasin, sedangkan sampelnya adalah siswa kelas VIII di SMPN 1 Banjarmasin, SMPN 7 Banjarmasin dan SMPN 14 Banjarmasin.. Analisis data dilakukan secara statistik inferensial. Hasil penelitian mengindikasikan bahwa (1) Terdapat perbedaan yang signifikan prestasi belajar siswa masing-masing model pembelajaran kooperatif tipe TAI dan Jigsaw sebelum dan sesudah perlakuan; (2) tidak terdapat perbedaan yang signifikan prestasi belajar siswa antara kecerdasan linguistik, matematis logis dan lainnya; (3) tidak terdapat perbedaan yang signifikan prestasi belajar siswa antara kecerdasan linguistik, matematis logis dan lainnya dalam pelaksanaan model pembelajaran tipe TAI; (4) tidak terdapat perbedaan yang signifikan prestasi belajar siswa antara kecerdasan linguistik, matematis logis dan lainnya dalam pelaksanaan model pembelajaran tipe Jigsaw; (5) Terdapat perbedaan yang signifikan prestasi belajar siswa dengan kecerdasan linguistik antara model pembelajaran tipe TAI dan Jigsaw.
\end{abstract}

Kata kunci: TAI, Jigsaw, Kecerdasan Majemuk, Matematika

\section{PENDAHULUAN}

Kualitas pendidikan memiliki pengaruh terhadap perkembangan dan kemajuan suatu bangsa. Segala perubahan dan permasalahan dapat diselesaikan dalam pendidikan yang diterima setiap individu melalui proses belajar. Kecerdasan seseorang dapat dikembangkan secara optimal melalui pendidikan yang berimplikasi terhadap kemampuan seseorang tersebut. Hal ini sangat dibutuhkan dalam era globalisasi saat ini yang menuntuT manusia untuk bisa beradaptasi dengan perkembangan teknologi saat ini. 
Kecerdasan merupakan salah satu karunia yang diberikan kepada manusia dibandingkan dengan makhluk lainnya. Dengan kecerdasan, manusia dapat terus menerus mempertahankan dan meningkatkan kualitas hidupnya yang semakin kompleks. Manusia dapat melakukannya melalui proses berpikir dan belajar secara terus menerus.

Kecerdasan berkaitan dengan kemampuan memahami lingkungan atau alam sekitar. Kecerdasan juga berhubungan dengan kemampuan penalaran atau berpikir logis dan sikap bertahan hidup dengan menggunakan sarana dan sumber-sumber yang ada yang memiliki komponen yaitu: (1) kemampuan untuk mengarahkan pikiran atau mengarahkan tindakan; (2) kemampuan untuk mengubah arah tindakan apabila tindakan tersebut telah dilaksanakan; (3) kemampuan untuk mengubah diri sendiri (Uno, 2006).

Diantara jenis kecerdasan yang berkembang dalam dunia pendidikan saat ini, terdapat satu yang tersorot, penting dan menarik yaitu kecerdasan majemuk. Beberapa penelitian terkait kecerdasan majemuk telah dilakukan oleh peneliti sebelumnya (lihat Abidin, 2017; Khiyarusoleh, 2018; Rofiah, 2016; Setiawan \& Nisa, 2018). Kecerdasan majemuk pertama kali dikemukakan oleh Howard Gardner. Teori ini menyatakan bahwa manusia itu memiliki berbagai macam kecerdasan dan setiap individu memiliki tingkat yang bervariasi untuk setiap jenis kecerdasan tersebut. Karena itu, setiap manusia memiliki "profil kognitif" yang unik. Gardner tidak memandang kecerdasan manusia berdasarkan skor tes standar semata. Gardner mengemukakan tentang kecerdasan yaitu: (1) kemampuan untuk menyelesaikan masalah yang terjadi dalam kehidupan manusia; (2) keterampilan memecahkan masalah membuat seseorang mendekati situasi yang sasarannya harus dicapai; (3) kemampuan untuk menemukan arah atau cara yang tepat ke arah sasaran tersebut (Riyanto, 2010).

Kecerdasan majemuk memberikan sebuah pengertian tentang tingkatan kecerdasan seseorang dimana tidak ada individu yang tidak cerdas dalam pelaksanaan pembelajaran di sekolah. Hal ini menjadikan pendidik untuk bisa memahami jenis kecerdasan yang dimiliki oleh siswa. Gardner menyebutkan bahwa terdapat variasi kecerdasan majemuk dari suatu individu yang terdiri dari kecerdasan linguistik, kecerdasan matematis logis, kecerdasan visual, kecerdasan kinestetik, kecerdasan musikal, kecerdasan interpersonal, kecerdasan intrapersonal, dan kecerdasan natural. 
Konsep kecerdasan majemuk merangsang kemampuan kognitif secara lebih adil. Berbagai aktivitas stimulasi kecerdasan dapat menstimulus berbagai kemampuan yang termasuk dalam kategori perkembangan kognitif (Musfiroh, 2014; Hartina, 2019). Mengembangkan kemampuan kognitif siswa yang berkaitan dengan prestasi belajar bisa dilakukan melalui pembelajaran di kelas dengan mengggunakan model pembelajaran yang bervariasi. Akan tetapi, terdapat faktor yang mempengaruhi prestasi belajar siswa yaitu (1) faktor internal atau faktor dari dalam siswa, yaitu keadaan atau kondisi jasmani dan rohani siswa. Faktor internal meliputi dua aspek, yaitu aspek fisiologis yang bersifat jasmaniah dan aspek psikologis yang bersifat rohaniah. (2) faktor eksternal atau faktor dari luar siswa, yaitu kondisi lingkungan di sekitar siswa. Faktor eksternal siswa terdiri atas dua macam, yaitu faktor lingkungan sosial dan faktor lingkungan non sosial; (3) faktor pendekatan belajar (approach to learning), yaitu jenis upaya belajar siswa yang meliputi strategi dan metode yang digunakan siswa untuk melakukan kegiatan pembelajaran materi-materi pelajaran (Syah, 2008).

Pada umumnya nilai yang dicapai siswa SMP pada pelajaran matematika cenderung kurang memuaskan. Salah satu materi yang dianggap sulit oleh sebagian besar siswa kelas VIII adalah pokok bahasan Sistem Persamaan Linear Dua Variabel (SPLDV). Berdasarkan data dari Pusat Penilaian Pendidikan Kementerian Pendidikan dan Kebudayaan tahun 2018, daya serap siswa pada pokok bahasan SPLDV masih sangat rendah. Hal ini dapat dilihat dari rerata nilai hasil Ujian Nasional khususnya dalam menyelesaikan soal cerita SPLDV adalah 35,21 (Penilaian, 2018, Hikmah, 2019). Banyak siswa yang merasa kesulitan dalam menyelesaikan soal. Hal ini mungkin karena mereka belum menguasai konsep-konsep dasarnya.

Kualitas pembelajaran dapat ditingkatkan melalui beragam cara, salah satunya yaitu dengan pembaharuan pendekatan atau peningkatan relevansi metode mengajar. Metode mengajar dikatakan relevan jika dalam prosesnya mampu mengantarkan siswa mencapai tujuan pendidikan melalui pembelajaran namun dalam kenyataannya masih banyak guru yang mengajar secara monoton yaitu hanya menggunakan satu metode saja. Misalnya metode konvensional, Padahal belum tentu setiap pokok bahasan suatu materi pelajaran cocok dan efektif diajarkan dengan metode konvensional.

Upaya meningkatkan keaktifan siswa dapat dilakukan melalui pembelajaran yang sesuai. Salah satunya adalah pembelajaran kooperatif dimana kerjasama antar anggota 
melalui pembelajaran berkelompok untuk mempelajari materi yang diberikan dapat terjalin. Selain itu, tanggung jawab siswa tidak hanya untuk dirinya, melainkan juga terhadap kelompok yang merupakan ciri dalam pembelajaran kooperatif.

Pembelajaran kooperatif merupakan model pembelajaran yang pada hakikatnya melibatkan tugas yang memungkinkan siswa saling membantu dan mendukung dalam menyelesaikan tugas. Siswa mempunyai banyak kesempatan untuk mengolah informasi dan meningkatkan keterampilan berkomunikasi. Pembelajaran kooperatif yang dimaksud yaitu Jigsaw dan Team Assisted Individualization (TAI). Keberhasilan proses pembelajaran mungkin dipengaruhi oleh model pembelajaran tetapi mungkin juga dipengaruhi oleh kecerdasan seseorang. Oleh karena itu, pada artikel ini akan diuraikan bagaimana prestasi belajar siswa dalam model pembelajaran kooperatif tipe jigsaw ditinjau dari kecerdasan majemuk. Kecerdasan majemuk dalam hal ini terdiri dari 3 komponen yaitu kecerdasan linguistik, kecerdasan logikal dan sisanya dikategorikan sebagai kecerdasan lainnya.

\section{METODE}

Jenis penelitian yang dilakukan adalah eksperimen semu. Variabel penelitian ini terdiri dari variabel bebas dan variabel terikat. Variabel bebas dalam penelitian ini adalah model pembelajaran dan kecerdasan majemuk siswa, sedangkan variabel terikatnya adalah prestasi belajar siswa. Prestasi belajar siswa merupakan hasil belajar siswa dalam menyelesaikan tes yang diberikan.

Populasi penelitian ini adalah siswa kelas VIII SMP se-kota Banjarmasin. Sampel penelitian ini adalah siswa kelas VIII SMPN 1 Banjarmasin, SMPN 7 Banjarmasin dan SMPN 14 Banjarmasin yang diambil secara acak. Pengumpulan data dilakukan dengan teknik tes dan non tes. Teknik tes dilakukan untuk mengumpulkan data prestasi belajar, sedangkan teknik non tes dilakukan dengan menggunakan angket untuk mengetahui kecerdasan majemuk siswa.

Analisis data dilakukan secara statistik inferensial dengan melakukan perbandingan (1) prestasi belajar dua model pembelajaran tanpa melibatkan kecerdasan majemuk; (2) prestasi belajar 3 kategori dari kecerdasan majemuk sekaligus; (3) prestasi belajar pada model pembelajaran kooperatif tipe TAI ditinjau dari kecerdasan majemuk; (4) prestasi belajar model pembelajar kooperatif tipe Jigsaw ditinjau dari kecerdasan 
majemuk; (5) prestasi belajar dua model pembelajaran yang ditinjau dari kecerdasan majemuk.

\section{HASIL DAN PEMBAHASAN}

Berdasarkan 3 sekolah yang diambil sampel penelitian secara keseluruhan, terdapat 13,48\% siswa dengan kecerdasan logikal, 20,79\% siswa dengan kecerdasan linguistik dan $65,73 \%$ siswa dengan kecerdasan lainnya. Sedangkan, hasil belajar siswa

Tabel 1. Hasil Belajar Siswa

\begin{tabular}{lccccccccc}
\hline & \multicolumn{3}{c}{} & SMPN 1 & \multicolumn{3}{c}{ SMPN 7 } & \multicolumn{5}{c}{ SMPN 14 } \\
\hline \multirow{3}{*}{ TAI } & Pre & Post & Selisih & Pre & Post & Selisih & Pre & Post & Selisih \\
\cline { 2 - 10 } Jigsaw & 14,06 & 76,09 & 62,03 & 14,17 & 71,50 & 57,33 & 19,64 & 75,00 & 55,36 \\
& 15,32 & 71,94 & 56,61 & 17,67 & 72,00 & 54,33 & 18,28 & 75,00 & 56,72 \\
\hline
\end{tabular}

pada pembelajaran kooperatif tipe TAI dan Jigsaw di masing-masing sekolah dapat dilihat pada tabel 1 .

Hasil belajar siswa pada tabel 1 belum berdasarkan pada kecerdasan majemuk siswa, melainkan perbandingan berdasarkan prestasi belajar siswa yang diperoleh tanpa melibatkan kecerdasan tersebut. hasil pengujian secara parametrik prestasi belajar siswa yang menggunakan model pembelajaran kooperatif tipe TAI dan Jigsaw dapat dilihat pada tabel 2 .

Tabel 2. Uji t Berpasangan

\begin{tabular}{llll}
\hline & & Correlation & Sig. \\
\hline Pair 1 & Pre_TAI_SMPN1 \& Post_TAI_SMPN1 & 0,38 & 0,03 \\
Pair 2 & Pre_Jigsaw_SMPN1 \& Post_jigsaw_SMPN1 & 0,69 & 0,00 \\
Pair 3 & Pre_TAI_SMPN7 \& Post_TAI_SMPN7 & 0,67 & 0,00 \\
Pair 4 & Pre_Jigsaw_SMPN7 \& Post_Jigsaw_SMPN7 & 0,84 & 0,00 \\
Pair 5 & Pre_TAI_SMPN14 \& Post_TAI_SMPN14 & 0,54 & 0,00 \\
Pair 6 & Pre_Jigsaw_SMPN14 \& Post_Jigsaw_SMPN14 & 0,74 & 0,00 \\
\hline
\end{tabular}

Nilai signifikansi uji $\mathrm{t}$ berpasangan mengindikasikan bahwa setiap model pembelajaran, baik TAI dan Jigsaw memiliki pengaruh terhadap hasil belajar di masingmasing sekolah. Hal ini juga menunjukkan bahwa pembelajaran dengan menggunakan model pembelajaran TAI dan Jigsaw memiliki kesamaan dalam meningkatkan prestasi belajar siswa. 
Hasil analisis perbandingan prestasi belajar siswa berdasarkan kecerdasan majemuk setelah data dilakukan pengujian normalitas dan homogenitas yang menghasilkan data tidak berdistribusi normal, tetapi homogen. Karena salah satu syarat uji parametrik tidak terpenuhi, maka dilakukan pengujian secara non parametrik dengan menggunakan uji Kruskal Wallis yang dapat dilihat pada tabel 3. Nilai signifikansi yang diperoleh melebihi dari taraf signifikan 10\%, Hal ini menunjukkan bahwa tidak terdapat perbedaan signifikan antara kecerdasan linguistik, matematis logis dan kecerdasan lainnya.

Tabel 3. Uji Kruskal Wallis

\begin{tabular}{lc}
\hline & Prestasi Belajar \\
\hline Chi-Square & 0,374 \\
Df & 2 \\
Asymp. Sig & 0,829 \\
\hline
\end{tabular}

Perbandingan prestasi hasil belajar ditinjau dari kecerdasan majemuk pada model pembelajaran TAI menghasilkan data yang berdistribusi normal dan homogen, sehingga pengujian dapat dilakukan secara parametrik dengan menggunakan uji anova yang terdapat pada tabel 4. Hasil analisis diperoleh bahwa nilai signifikansi anova berada di atas taraf signifikansi 10\%, sehingga dapat disimpulkan bahwa tidak terdapat perbedaan antara kecerdasan linguistik, matematis logis, dan lainnya.

Tabel 4. Uji Anova Perbandingan Prestasi Belajar pada TAI

\begin{tabular}{llllll}
\hline & sum of square & df & Mean of square & f & sig \\
\hline Between Groups & 427,000 & 2 & 213,500 & 0,743 & 0,479 \\
Within Groups & 25014,389 & 87 & 287,522 & & \\
Total & 25441,389 & 89 & & & \\
\hline
\end{tabular}

Perbandingan prestasi belajar ditinjau dari kecerdasan majemuk pada model pembelajaran jigsaw menghasilkan data yang tidak berdistribusi normal, tetapi homogen. Hal ini mengakibatkan analisis dilakukan secara non parametrik yang dapat dilihat pada tabel 5 .

Tabel 5. Uji Kecerdasan Majemuk pada Jigsaw

\begin{tabular}{lc}
\hline & Prestasi Belajar \\
\hline Chi-Square & 1,198 \\
df & 2 \\
Asymp. Sig & 0,549 \\
\hline
\end{tabular}


Hasil analisis yang diperoleh menunjukkan nilai Asymp. Sig melebihi taraf signifikansi $10 \%$. Hal ini mengindikasikan bahwa tidak terdapat perbedaan signifikan antara kecerdasan linguistik, matematis logis, dan kecerdasan lainnya pada model pembelajaran kooperatif tipe jigsaw.

Perbandingan prestasi belajar model pembelajaran kooperatif tipe TAI dan Jigsaw ditinjau dari kecerdasan majemuk menghasilkan data berdistribusi normal, sehingga dapat dilakukan pengujian statistik secara parametrik, kecuali untuk data prestasi belajar siswa dengan kecerdasan lainnya. Pengujian akan dilakukan dengan menggunakan uji t Independen, sehingga pengujian homogenitas tidak diperlukan. Adapun hasil pengujian $\mathrm{t}$ berpasangan dapat dilihat pada tabel 6 , sedangkan prestasi belajar siswa dengan kecerdasan lainnya dianalisis secara non parametrik dengan menggunakan uji Mann Whitney yang dapat dilihat pada tabel 7.

Tabel 6. Uji t Independen

\begin{tabular}{llll}
\hline & $\mathrm{t}$ & $\mathrm{df}$ & Sig. (2-tailed) \\
\hline K. Matematis Logis Tai-Jigsaw & 0,604 & 22 & 0,552 \\
K.Linguistik Tai-Jigsaw & 1,880 & 37 & 0,068 \\
\hline
\end{tabular}

Tabel 7. Uji Mann Whitney

\begin{tabular}{ll}
\hline & Prestasi_Belajar_KLA \\
\hline Mann-Whitney U & 1647,000 \\
Wilcoxon W & 3243,000 \\
Z &,- 336 \\
Asymp. Sig. (2-tailed) &, 737 \\
\hline
\end{tabular}

a. Grouping Variable: Model_pembelajaran

Berdasarkan hasil analisis pada tabel 6 dan tabel 7 diperoleh bahwa nilai signifikansi melebihi taraf signifikansi 10\%, kecuali kecerdasan linguistik. Hal ini mengindikasikan bahwa terdapat perbedaan yang signifikan untuk kecerdasan linguistik antara model pembelajaran tipe TAI dan Jigsaw. Sedangkan untuk kecerdasan matematis logis dan lainnya masing-masing mengindikasikan tidak terdapat perbedaan yang signifikan antara model TAI dan Jigsaw.

Pelaksanaan pembelajaran kooperatif tipe TAI dan Jigsaw pada siswa SMP memiliki pengaruh terhadap prestasi belajar siswa. Hasil belajar siswa mengalami perubahan sesudah diberikannya perlakuan. Pembelajaran kooperatif adalah konsep yang berkaitan dengan semua jenis kerja kelompok, khususnya yang dilakukan oleh guru atau arahannya dalam memimpin kelompok tersebut. Umumnya, guru lebih banyak memberikan arahan dalam pembelajara kooperatif dimana tugas dan pertanyaaan, serta bahan dan informasi yang dirancang yang telah ditetapkan oleh guru 
dapat membantu siswa dalam memecahkan suatu masalah. Hal ini biasanya guru menetapkan bentuk ujian diakhir penugasan (Suprijono, 2010)

Prestasi belajar siswa berdasarkan kecerdasan majemuk siswa yang terdiri dari kecerdasan linguistik, kecerdasan matematis logis dan kecerdasan lainnya tidak memiliki perbedaan secara signifikan. Hal ini mengindikasikan bahwa setiap jenis kecerdasan siswa memiliki kesamaan dalam proses memecahkan masalah yang diberikan. Hal ini selaras dengan temuan pada pembelajaran kooperatif tipe TAI dan Jigsaw dimana tidak terdapat perbedaan prestasi belajar antar jenis kecerdasan majemuk siswa yang telah dikategorikan.

Potensi yang dimiliki siswa haruslah diperhatikan oleh guru dalam proses pembelajaran matematika agar tumbuh secara optimal, khususnya dalam kecerdasan. Kecerdasan yang dimiliki siswa masing-masing memiliki perbedaan yang haruslah disadari oleh guru. Materi pembelajaran dapat dikemas secara menarik sesuai dengan kondisi lokal dan potensi yang dimiliki oleh peserta didik. Dengan demikian, materi yang disesuaikan dengan kondisi riil yang ada dapat terbantu melalui pelaksanaan pembelajaran matematika berdasarkan tingkat kecerdasan yang berbeda (Amir, 2013).

Lebih jauh, prestasi belajar untuk masing-masing jenis kecerdasan dengan perbandingan model pembelajaran kooperatif tipe TAI dan Jigsaw, hanya terjadi perbedaan pada jenis kecerdasan linguistik. Prestasi belajar siswa dengan kecerdasan linguistik pada model pembelajaran TAI lebih baik daripada Jigsaw. Hal ini dikarenakan Model pembelajaran kooperatif tipe TAI menjadikan siswa untuk dapat memberikan bantuan berupa bimbingan kepada teman yang membutuhkan, sehingga proses belajar siswa dengan kecerdasan linguistik dapat mengembangkan keterampilannya untuk memecahkan masalah matematika yang diberikan.

\section{SIMPULAN DAN SARAN}

Simpulan yang diperoleh dari hasil penelitian yang telah dijabarkan yaitu (1) Terdapat perbedaan yang signifikan prestasi belajar siswa masing-masing model pembelajaran kooperatif tipe TAI dan Jigsaw sebelum dan sesudah perlakuan; (2) tidak terdapat perbedaan yang signifikan prestasi belajar siswa antara kecerdasan linguistik, matematis logis dan lainnya; (3) tidak terdapat perbedaan yang signifikan prestasi belajar siswa antara kecerdasan linguistik, matematis logis dan lainnya dalam pelaksanaan model pembelajaran tipe TAI; (4) tidak terdapat perbedaan yang signifikan 
prestasi belajar siswa antara kecerdasan linguistik, matematis logis dan lainnya dalam pelaksanaan model pembelajaran tipe Jigsaw; (5) Terdapat perbedaan yang signifikan prestasi belajar siswa dengan kecerdasan linguistik antara model pembelajaran tipe TAI dan Jigsaw. Dengan demikian, berdasarkan simpulan yang diperoleh, maka saran dalam penelitian ini yakni perlu adanya penelitian lanjutan berkaitan dengan pengembangan buku ajar berbasis kecerdasan majemuk dalam pembelajaran matematika.

\section{UCAPAN TERIMA KASIH}

Terima kasih kepada Kemenristek DIKTI yang sebesar-besarnya dalam membiayai keseluruhan penelitian ini.

\section{DAFTAR PUSTAKA}

Abidin, Z. (2017). Pengembangan Kecerdasan Majemuk (Multiple Intelligences) Di Madrasah. Elementary: Jurnal Ilmiah Pendidikan Dasar, 3(2), 120. Https://Doi.Org/10.32332/Elementary.V3i2.832

Amir, A. (2013). Pembelajaran Matematika Dengan Menggunakan Kecerdasan Majemuk (Multiple Intelligences). Logaritma, I(1), 1-14. Https://Doi.Org/10.1111/Jofi.12406

Hartina, H., Sanapiah, S., \& Yuliyanti, S. (2019). Pembelajaran Berkerangka Elpsa Untuk Meningkatkan Hasil Belajar Statistika Pada Siswa Kelas Vii Mts Asy-Syafi'iyah Bendung. Media Pendidikan Matematika, 7(1), 58-71.

Hikmah, A., Roza, Y., \& Maimunah, M. (2019). Analisis Kemampuan Komunikasi Matematis Siswa SMP pada Soal SPLDV. Media Pendidikan Matematika, 7(1), 29-35.

Khiyarusoleh, U. (2018). Kecerdasan Logika-Matematika Di Lihat Dari Kecerdasan Majemuk Siswa Sma Di Brebes Selatan. Naturalistic: Jurnal Kajian Penelitian Pendidikan Dan Pembelajaran, 3(1), 240-246. Https://Doi.Org/10.35568/Naturalistic.V3i1.270

Musfiroh, T. (2014). Pengembangan Kecerdasan Majemuk. Universitas Terbuka.

Penilaian, Pusat. (2018). Daya Serap. Jakarta: Kemendikbud.

Riyanto, Y. (2010). Paradigma Baru Pembelajaran. Kencana.

Rofiah, N. H. (2016). Menerapkan Multiple Intelligences Dalam Pembelajaran Di Sekolah Dasar. Jurnal Dinamika Pendidikan Dasar, 8(1), 69-79. Http://Jurnalnasional.Ump.Ac.Id/Index.Php/Dinamika/Article/View/937/875

Setiawan, D., \& Nisa, K. (2018). Kajian Kecerdasan Majemuk Pada Beberapa Model Pembelajaran Kooperatif. Semdikjar 2, 215-222.

Suprijono, A. (2010). Cooperative Learning Teori Dan Aplikasi Paikem. Pustaka Belajar.

Syah, M. (2008). Psikologi Pendidikan Dengan Pendekatan Baru. PT. Remaja Rosdakarya.

Uno, H. B. (2006). Orientasi Baru Dalam Psikologi Pembelajaran. PT. Bumi Aksara. 